\title{
PEMANFAATAN LERAK PADA BATA FOAM YANG RAMAH LINGKUNGAN
}

\author{
Davizar Rukman Arrumy ${ }^{1}$, Sri Sumarni ${ }^{2}$, Chundakus Habsya ${ }^{2}$ \\ email: adavizar@yahoo.com
}

\begin{abstract}
Abstrak
Penelitian ini bertujuan untuk mengetahui perbedaan pengunaan busa lerak variasi foam $30 \%$ dan $40 \%$ dengan perbandingan 1pc:1ps dan 1pc:2ps terhadap kuat tekan, berat jenis, daya serap air dan nilai maksimal kuat tekan beton ringan foam. Penelitian ini menggunakan metode kuantitatif experimen dan teknik analisa data menggunakan analisis T-Test. Variabel yang membedakan penelitian ini adalah variabel terikat: kuat tekan, berat jenis dan daya serap air bata beton ringan foam, varibel bebas: penggunaan busa lerak perbandingan semen dan pasir seperti tersebut diatas.

Berdasarkan hasil penelitian bahwa, terdapat perbedaan penggunaan busa lerak dengan variasi persentase busa dan perbandingan semen dengan pasir terhadap kuat tekan, berat jenis, daya serap air serta menghasilkan kuat tekan maksimal sebesar 6,583 MPa pada $30 \%$ busa lerak dengan perbandingan $1 \mathrm{pc}: 1 \mathrm{ps}$.
\end{abstract}

Kata Kunci: busa lerak, bata beton ringan foam, kuat tekan, berat jenis, daya serap air.

\footnotetext{
${ }^{1}$ Mahasiswa Program Studi Pendidikan Teknik Bangunan Universitas Sebelas Maret

${ }^{2}$ Pengajar Program Studi Pendidikan Teknik Bangunan Universitas Sebelas Maret
} 


\title{
UTILIZATION OF LERAK ON BRICK FOAM WICH IS ENVIRONMENTALLY FRIENDLY
}

\author{
Davizar Rukman Arrumy ${ }^{1}$, Sri Sumarni ${ }^{2}$, Chundakus Habsya ${ }^{2}$ \\ Email: Adavizar@yahoo.com
}

\begin{abstract}
This research is used to know the differences in the use of foam Lerak foam variations $30 \%$ and $40 \%$ with comparasion $1 \mathrm{pc}$ : $1 \mathrm{ps}$ and $1 \mathrm{pc}: 2 \mathrm{ps}$ against compressive strength, density, water absorption and maximum value of compressive strength of lightweight concrete foam. This research uses quantitative methods of experiment and data analysis techniques using T-Test analysis. The variables that distinguishes this research are dependent variables : compressive strength, density and absorption capacity of lightweight concrete brick foam, independent variables: the use of foam lerak with comparision cement and sand ratio as mentioned above.

Based on this research result, there are difference of foam lerak with variation of percentage of foam and cement comparision with sand to compressive strength, density, water absorption and yield maximum compressive strength of $6,583 \mathrm{MPa}$ at $30 \%$ foam lerak with comparision $1 \mathrm{pc}: 1 \mathrm{ps}$.
\end{abstract}

Keywords: Foam Lerak, concrete light foam, compressive strength, and absorption of water.

\footnotetext{
${ }^{1}$ Student Of Civil Enginering Education On Sebelas Maret University

${ }^{2}$ Lecture Of Civil Enginering Education On Sebelas Maret University
} 


\section{PENDAHULUAN}

Indonesia merupakan salah satu negara yang sedang berkembang. Kebutuhan material konstruksi bangunan semakin meningkat, seperti pembangunan rumah tinggal dan gedung bertingkat sesuai kebutuhan masyarakat.

Menurut Belaguru dan Foden (1996) beton ringan adalah komponen bangunan penting yang sudah berhasil digunakan dalam 30 tahun. Menurut SNI-03-2847-2002, beton ringan adalah beton yang mengandung agregat ringan dan mempunyai berat satuan dengan kepadatan lebih kecil dari $1900 \mathrm{~kg} / \mathrm{m}^{3}$. Penggunaan beton ringan pada konstruksi bangunan bertingkat dapat mengurangi berat bangunan sendiri dan berdampak kepada dimensi struktur. Beton ringan memiliki keuntungan antara lain: memiliki nilai tahan panas yang baik, memiliki tahanan suara (peredam) yang baik dan ketahanan api yang baik (Sumarno, 2010).

Menurut

Tjokrodimuljo (2004:XII-1) beton ringan dapat dibuat dengan beberapa cara yaitu pertama dengan membuat gelembung gas/udara dalam adukan semen sehingga banyak pori-pori udara dalam beton. Kedua, menggunakan semen dengan agregat ringan, misalnya tanah liat, batu apung atau fly ash untuk adukan semen sehingga beton yang menghasilkan beton lebih ringan dari beton normal. Ketiga beton tanpa agregat halus atau sering disebut beton non pasir.

Bata beton ringan foam adalah bata beton ringan yang dibuat dari bahan semen, agregat halus dan foam. Foam atau busa dibuat tersendiri melalui generator foam, dan berfungsi untuk meringankan bata beton ringan foam yang dihasilkan. Agregat halus berfungsi sebagai bahan pengisi. Walaupun hanya sebagai bahan pengisi, agregat halus juga berperan dalam menentukan kualitas dan sifat-sifat beton yang dihasilkan karena sebagian besar bata beton ringan foam diisi oleh agregat halus.

Semakin banyak kebutuhan akan bata beton ringan foam mengakibatkan peningkatan kebutuhan material penyusun bata beton ringan foam, salah satunya adalah foam agent. Foam agent adalah suatu larutan pekat dari bahan surfaktan, dimana apabila hendak digunakan harus dilarutkan dengan air. Dengan membuat gelembunggelembung gas/udara dalam adukan semen, dengan demikian akan terjadi banyak pori-pori udara di dalam betonnya (Afaza, 2014). Terdapat dua jenis foam agent antara lain jenis sintetik yang merupakan produk kimia murni dan jenis protein/ organik berbasis protein hewani (Khalid, 2011). Salah satu alternatif pengganti foam agent jenis sintetik yang berbasis kimia murni guna mengurangi dampak negatif pada lingkungan yaitu dengan memanfaatkan bahan ramah lingkungan seperti busa buah lerak. Sumber daya alam berupa busa buah lerak yang kurang dioptimalkan dalam pemanfaatannya dimungkinkan mampu meningkatkan kuat tekan bata beton ringan foam.

Menurut Sulisetijono, dkk (2016) buah lerak mengandung saponin yang dapat menghasilkan busa dan berfungsi sebagai bahan pencuci, dapat pula dimanfaatkan sebagai pembersih berbagai peralatan dapur dan baju batik. Keunikan dan kelebihan lerak dibandingkan dengan sabun atau deterjen kimia adalah lebih ekologis dan ekonomis. Limbah lerak dapat diuraikan oleh alam dan tingkat pencemarannya hampir tidak ada. Kandungan racun biji lerak dapat digunakan sebagai insektisida dan air bekas cucian bisa diurai mikroorganisme sehingga tidak mencemari lingkungan (Rosyidah, 2013). 
Menurut Adriani (2016) dalam pembuatan beton ringan dengan material penyusunnya yaitu semen, kapur, air dan foam organik yang dihasilkan dari ekstrak buah lerak menggunakan perbandingan semen dan kapur 1:4. Foam lerak tersebut dicampurkan ke dalam mortar sehingga memberikan banyak rongga didalamnya. Dalam pengujian ini beton dengan kadar foam lerak $60 \%, 70 \%$ dan $80 \%$ memiliki nilai kuat tekan saat umur 28 hari sebesar 1,271 Mpa, 0,543 Mpa dan 0,341 Mpa. Nilai daya serap air $36,34 \%, 43,65 \%$ dan $60,59 \%$. Nilai berat jenis $1,149 \mathrm{gr} / \mathrm{cm}^{3}$, $0,894 \mathrm{gr} / \mathrm{cm}^{3}$ dan $0,879 \mathrm{gr} / \mathrm{cm}^{3}$.

Prakoso, (2014) dalam Andriani (2016) melakukan penelitian mortar ringan dengan material penyusun yaitu semen, pasir, air dan foam organik yang dihasilkan dari ekstrak buah lerak menggunakan perbandingan semen dan pasir 1:2, 1:2,5 dan 1,3 akibatnya berat jenis beton menjadi lebih ringan. Dalam penelitian ini, Prakoso meneliti sifat fisik dan mekanik dari mortar ringan dengan kadar busa organik $50 \%$ terhadap volume mortar. Nilai kuat tekan beton dengan fas 0,6 umur 28 hari dengan perbandingan pc: pasir 1:2, 1:2,5 dan 1:3 arti berturut-turut 7,65 Mpa, 2,81 Mpa, 1,60 Mpa sedangkan variasi fas 0,5 dengan perbandingan semen : pasir yaitu 1:2 nilai kuat tekan 4,56 $\mathrm{MPa}$. Nilai daya serap air dengan fas 0,6 yaitu $25,03 \%, 21,83 \%$ dan 19,85 variasi fas 0,5 dengan perbandingan semen : pasir yaitu 1:2 daya serap air $17,44 \%$. Nilai berat jenis dengan fas 0,6 yaitu 1,52 $\mathrm{gr} / \mathrm{cm}^{3}, 1,27 \mathrm{gr} / \mathrm{cm}^{3}, 1,18 \mathrm{gr} / \mathrm{cm}^{3}$ variasi fas 0,5 dengan perbandingan semen : pasir yaitu 1:2 berat jenis $1,44 \mathrm{gr} / \mathrm{cm}^{3}$.

Berdasarkan hasil penelitian Megayantha, (2013) dalam Andriani (2016:21) pembuatan beton ringan dengan penyusunnya yaitu pasir, semen dan foam organik yang dihasilkan dari ekstrak buah lerak menggunakan perbandingan semen dan pasir 1:1,5. Dalam pengujian ini beton dengan kadar foam lerak $30 \%$ dan $90 \%$ memiliki nilai kuat tekan saat umur 28 hari sebesar 2,491 Mpa dan 1,371 Mpa. Nilai daya serap air $21,60 \%$ dan $27,72 \%$. Nilai berat jenis $1,049 \mathrm{gr} / \mathrm{cm}^{3}$ dan $0,832 \mathrm{gr} / \mathrm{cm}^{3}$.

Menurut Hamad (2014) menjelaskan foam mempunyai kandungan yang baik untuk beton ringan. Hasil pengujian Vian Andriani (2016) menunjukkan bahwa semakin banyak kadar foam organik dalam campuran beton maka kuat tekan akan semakin menurun. Berat jenisnya pun juga akan semakin ringan. Untuk nilai daya serap air justru akan semakin besar seiring bertambahnya kadar foam karena kandungan rongga semakin banyak.

Penelitian ini tentang pemanfaatan busa lerak sebagi bahan pengganti cairan kimia foam agent ADT (Additive Foam Concrete) pada bata beton ringan foam. Selanjutnya pada penelitian ini bertujuan untuk mengetahui perbedaan kuat tekan, berat jenis dan daya serap air dari bata beton ringan foam dengan kandungan volume busa lerak $30 \%$ dan $40 \%$. Dengan adanya penelitian ini diharapkan dapat menghasilkan kuat bata beton ringan foam yang optimal, sehingga lerak dapat menjadi bahan pengganti cairan kimia foaming agent ADT (Additive Foam Concrete) pada bata beton ringan foam.

\section{METODE PENELITIAN}

Penelitian ini dilakukan di dua tempat, yaitu untuk pengujian bahan uji, daya serap air dan berat jenis dilakukan di laboratorium PTB FKIP UNS dan untuk kuat tekan pengujian di laboratorium Teknik Sipil Universitas Sebelas Maret Surakarta. Jenis penelitian ini merupakan penelitian kuantitatif eksperimen yaitu dengan mengambil gambaran mengenai perbedaan lerak sebagai pengganti 
cairan foaming agent ADT (Additive Foam Concrete) terhadap kuat tekan, berat jenis dan daya serap air beton ringan foam dengan perbandingan campuran 1pc:1ps dan 1pc:2ps. Gambaran ini dibuat dengan melakukan eksperimen terhadap sejumlah benda uji untuk mendapatkan data yang dibutuhkan. Populasi pada penelitian ini adalah bata beton ringan foam dengan panggantian cairan foaming agent ADT (Additive Foam Concrete) yaitu busa lerak. Menggunakan benda uji silinder sesuai dengan SNI 3-3421-1994 dengan diameter $75 \mathrm{~mm}$ dan tinggi $150 \mathrm{~mm}$ pada pengujian kuat tekan sesuai SNI 033421-1994, pengujian berat jenis sesuai SNI-03-1973-1990 dan pengujian daya serap air sesuai SNI-03-0691-1996. Dalam penelitian ini jumlah sampel yang digunakan untuk pengujian kuat tekan, berat jenis dan daya serap air bata beton ringan foam adalah 5 sampel untuk setiap variasinya. Bahan yang digunakan untuk penelitian ini adalah semen portland tipe 1 yang digunakan untuk konstruksi umum tanpa memerlukan persyaratan khusus (Tjokrodimuljo, 2004), pasir yang memiliki diameter 1mm-5mm (Ali Asroni,2010) dan klasifikasi pasir berdasarkan distribusi ukuran butiran sesuai dengan SK-SNI-T15-1990-03, air yang digunakan sesuai dengan SK-SNI S-04-1989-03 F dan lerak.

Teknik pengumpulan data dalam penelitian ini dengan melaksanakan pengujian kuat tekan, berat jenis dan daya serap air bata beton ringan foam. Teknik analisa data yang digunakan adalah $T$-test.

\section{HASIL DAN PEMBAHASAN}

\section{Hasil Pengujian Agregat}

Tabel 1. Hasil Pengujian Agregart

Hasil Pengujian Agregat Halus

\begin{tabular}{cccc}
\hline Parameter & Hasil & Standar & Keterangan \\
\hline $\begin{array}{c}\text { Kadar } \\
\text { lumpur }\end{array}$ & $4,36 \%$ & $<5 \%$ & $\begin{array}{c}\text { Memenuhi } \\
\text { persyaratan }\end{array}$ \\
\hline $\begin{array}{c}\text { Kadar zat } \\
\text { organik }\end{array}$ & $0-10 \%$ & - & $\begin{array}{c}\text { Penurunan } \\
\text { kekuatan }\end{array}$ \\
\hline Kadar air & $0,3 \%$ & $1-3 \%$ & $\begin{array}{c}\text { Belum } \\
\text { memenuhi } \\
\text { persyaratan }\end{array}$ \\
\hline $\begin{array}{c}\text { Bulk } \\
\text { specific } \\
\text { Gravity } \\
\text { SSD }\end{array}$ & 2,53 & $2,5-2,7$ & $\begin{array}{c}\text { Termasuk } \\
\text { agregat } \\
\text { halus normal }\end{array}$ \\
\hline $\begin{array}{c}\text { Modulus } \\
\text { kehalusan }\end{array}$ & 3,33 & $1,5-3,8$ & $\begin{array}{c}\text { Memenuhi } \\
\text { persyaratan }\end{array}$ \\
\hline & $\begin{array}{c}\text { Termas } \\
\text { uk }\end{array}$ & & $\begin{array}{c}\text { Dapat } \\
\text { digunakan }\end{array}$ \\
& Daerah & &
\end{tabular}

Dari pengujian kadar air agregat halus belum memenuhi persyaratan yaitu nilai kadar air $<1-3 \%$ sebagaimana yang telah ditentukan pada SK SNI S-04-1989-F, maka dalam campuran bata beton ringan foam perlu penambahan air.

\section{Pengujian Kuat Tekan Bata Beton Ringan Foam}

Hasil pengujian kuat tekan bata beton ringan foam dengan persentase penambahan busa lerak $30 \%$ dan $40 \%$ pada campuran semen dan pasir 1:1 dan 1:2 dapat dilihat pada gambar $1 \mathrm{di}$ bawah ini : 


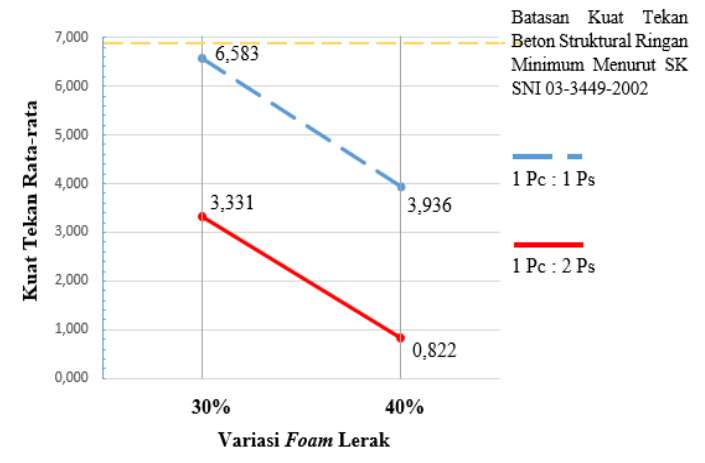

Gambar 1. Grafik Hubungan Variasi foam Lerak Terhadap Kuat tekan Bata Beton Ringan Foam

Dari gambar 1 di atas dapat dilihat bahwa nilai kuat tekan ratarata bata beton ringan foam pada persentase $30 \%$ lebih besar dibandingkan persentase $40 \%$. Hal ini dipengaruhi oleh semakin banyak penambahan foam akan membentuk volume pori-pori dan nilai porositas yang meningkat sehingga benda uji yang dihasilkan memiliki banyak rongga yang membuat benda uji menjadi mudah keropos sehingga memberikan perbedaan penurunan terhadap kekuatan beton (Eko Hindaryanto Nugroho, 2010 dalam Ngarifin, 2015).

\section{Pengujian Berat Jenis Bata Beton Ringan Foam}

Hasil pengujian berat jenis bata beton ringan foam dengan persentase penambahan busa lerak $30 \%$ dan $40 \%$ pada campuran semen dan pasir 1:1 dan 1:2 dapat dilihat pada gambar $1 \mathrm{di}$ bawah ini :

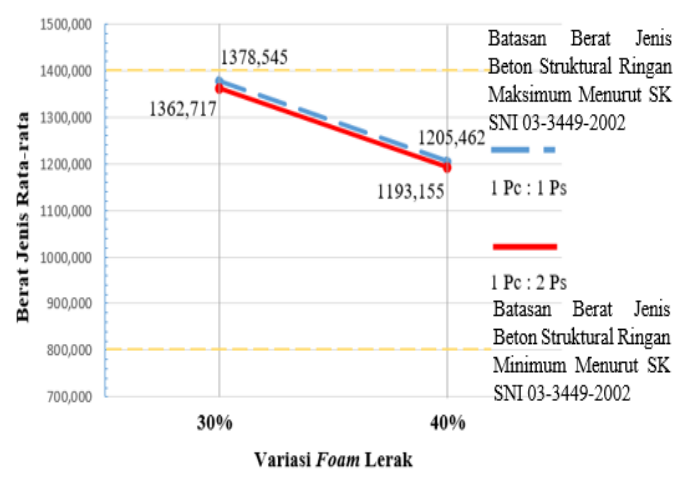

Gambar 2. Grafik Hubungan Variasi foam Lerak Terhadap Berat Jenis Bata Beton Ringan Foam

Dari gambar 2 di atas dapat dilihat bahwa nilai berat jenis ratarata bata beton ringan foam pada persentase $30 \%$ lebih besar dibandingkan persentase $40 \%$. Hal ini dipengaruhi oleh semakin sedikit penambahan foam akan menghasilkan nilai porositas dan rongga yang semakin sedikit atau dapat dikatakan bahwa beton ringan tersebut semakin padat dan menyebabkan berat jenis semakin meningkat (Eko Hindaryanto Nugroho, 2010 dalam Ngarifin, 2015).

\section{Pengujian Daya Serap Air Bata} Beton Ringan Foam

Hasil pengujian daya serap air bata beton ringan foam dengan persentase penambahan busa lerak $30 \%$ dan $40 \%$ pada campuran semen dan pasir 1:1 dan 1:2 dapat dilihat pada gambar 1 di bawah ini : 


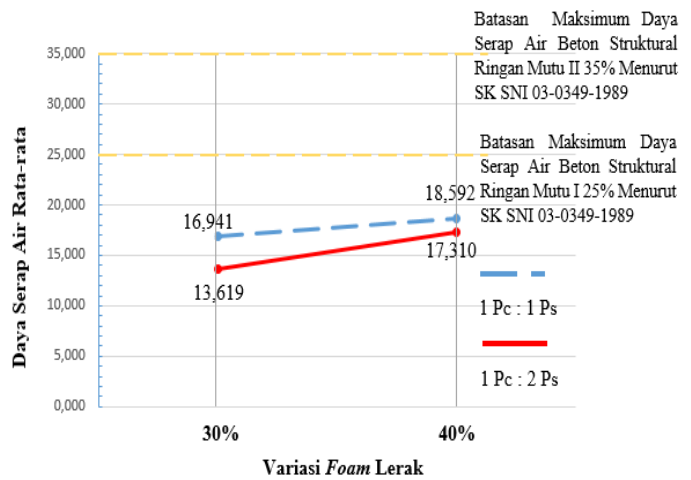

Gambar 3. Grafik Hubungan Variasi foam Lerak Terhadap Daya Serap Air

Bata Beton Ringan Foam

Dari gambar 3 di atas dapat dilihat bahwa nilai daya serap air ratarata bata beton ringan foam pada persentase $40 \%$ lebih besar dibandingkan persentase $30 \%$. Hal ini dipengaruhi oleh semakin besar nilai penambahan foam dan butir agregat yang tidak seluruhnya terbungkus mortar, demikian pula halnya ruang antar agregat tidak terisi penuh oleh mortar (Nugraha, Paul, 2007) akibat dari jumlah semen yang lebih sedikit dibandingkan jumlah agregat halus dalam penelitian ini berupa pasir, hal ini berdampak pada terbentuknya pori pori sehingga nilai porositas meningkat yang membuat benda uji menjadi mudah keropos sehingga memberikan perbedaan penurunan terhadap kekuatan beton (Eko Hindaryanto Nugroho, 2010 dalam Ngarifin, 2015) hal tersebut berbanding lurus dengan semakin banyak rongga maka semakin banyak beton menyerap air dan mengakibatkan nilai daya serap air meningkat.

\section{SIMPULAN}

Penelitian ini menghasilkan kesimpulan bahwa:

1. Terdapat perbedaan penggunaan busa lerak dengan variasi persentase busa dan perbandingan semen dengan pasir terhadap kuat tekan bata beton ringan foam.

2. Terdapat perbedaan penggunaan busa lerak dengan variasi persentase busa dan perbandingan semen dengan pasir terhadap berat jenis bata beton ringan foam.

3. Terdapat perbedaan penggunaan busa lerak dengan variasi persentase busa dan perbandingan semen dengan pasir terhadap daya resap air bata beton ringan foam.

4. Didapatkan persentase penambahan busa lerak dan perbandingan semen dengan pasir yang menghasilkan kuat tekan maksimal sebesar 6,583 Mpa yaitu pada persentase penambahan busa lerak sebesar $30 \%$ dan perbandingan $1 \mathrm{pc}: 1 \mathrm{ps}$ terkmasuk beton struktur ringan.

\section{SARAN}

1. Perlu adanya pengembangan penelitian lebih lanjut untuk pemanfaatan penggunaan busa lerak sebagai pengganti foam agent ADT dengan persentase penggunaan $30 \%$ dan perbandingan $1 \mathrm{pc}: 2 \mathrm{ps}$ terhadap uji konduktivitas thermal beton ringan foam.

2. Perlu ditinjau dari segi ekonomi dalam penelitian penggunaan busa lerak dalam pemanfaatan pada beton ringan foam.

\section{DAFTAR PUSTAKA}

Andriani, Vian. (2016). Pengaruh Variasi Foam Lerak pada Sifat Fisik dan Mekanik Beton Ringan dengan Perbandingan Campuran Semen dan Kapur 1:4. Sekripsi. Universitas Gadjah Mada. Yogyakarta.

Balagur, P., \& Foden, A. (1996). Properties of Reinforced Strucktural Lightweight Concrete. Journal Aci Structural. 
Hamad, A.J. (2014). Materials, Production and Application of Aerated Lightweight Croncret:Rivew. Journal of Materials Science and Engineering.

Khalid. (2011). Mechanical and Physical Properties Of Fly Ash Foamed Concrete. Tesis. Malaysia : Faculty of Civil and Environmental Engineering, University Tun Hussein Onn Malaysia ( UTHM).

M. Afaza, Muh. (2014). Pengaruh Penambahan Serat Polyethylene Pada Beton Ringan Dengan Teknologi Foam Terhadap Kuat Tekan, Kuat Tarik Belah Dan Modulus Elastisitas, Skripsi. Surakarta : Program Studi Teknik Sipil, Fakultas Teknik, Universitas Diponegoro.

Ngarifin. (2015). Pengaruh Penambahan Fly Ash Terhadap Kuat tekan, Berat Jenis dan Daya Hambat Panas Beton Ringan Foam Sebagai Suplemen Bahan Ajar Mata Kuliah Teknologi Beton Pada Semester III PTB JPTK UNS, Jurnal. Surakarta : FKIP Universitas Sebelas Maret.

Nugraha, Paul \& Antoni. (2007) Teknologi Beton dari material Pembuatan, Ke Beton Kinerja Tinggi, Yokyakarta: Andi.

Lina, Rosyidah. (2013). Pemanfaatan Lerak. Diperoleh pada 2 Maret 2018, dari https://rosyidahl.wordpress.com/ 2013/07/11/18/.

Standar Nasional Indonesia. (1990). SNI 03-1973-1990:Metode Pengujian Berat Isi Beton.

Standar Nasional Indonesia. (1994). SNI 03-3421-1994. Cara Uji Kuat
Beton Ringan Isolali. Badan standarisasi Nasional.

Standar Nasional Indonesia. (1996). SNI 03-0691-1996:Bata Beton (Paving Block).

Standar Nasional Indonesia. (2002). SNI 03-2847-2002. Tata Cara Perhitungan Struktur Beton Untuk Bangunan Gedung. Dewan Standarisasi Nasional.

Sulisetijono., dkk. (2016). Physical and Chemical Treatments to Break Seed Dormancy on Lerak (Sapindus Rarak DC.). Journal of Agriculture and Environmental Reearch.

Sumarno, (2010). Pemanfaatan Limbah Abu Terbang (fly ash) Batu bara dan Kulit Kerang Sebagai Bahan Substitusi Semen Serta Limbah Beton Sebagai Pengganti Pasir Dalam Pembuatan Bata Beton. Medan: Tesis.

Tjokrodimuljo, Kardiyono. (2004). Teknologi Beton. Yogyakarta: Universitas Gajah Mada. 